\section{AB0721 CLINICAL AND LABORATORY CHARACTERISTICS, GENETIC FEATURES OF MACROPHAGE ACTIVATION SYNDROME IN CHILDREN WITH SYSTEMIC-ONSET JUVENILE IDIOPATHIC ARTHRITIS: A SINGLE CENTER EXPERIENCE}

I. Kriulin ${ }^{1,2}$, E. Alexeeva ${ }^{1,2}$, T. Dvoryakovskaya ${ }^{1,2}$, K. Savostyanov ${ }^{3}$, A. Pushkov ${ }^{3}$, K. Isaeva ${ }^{1}$, R. Denisova ${ }^{1}$, O. Lomakina ${ }^{1}$, A. Mamutova ${ }^{1}$, A. Chomakhidze ${ }^{1}$, A. Fetisova ${ }^{1}$, M. Gautier ${ }^{1}$, E. Krekhova ${ }^{1,2}$, I. Tsulukiya ${ }^{1}$, A. Gromov ${ }^{2} .{ }^{1}$ National Medical Research Center of Children's Health, Rheumatology, Moscow, Russian Federation; ${ }^{2}$ Sechenov First Moscow State Medical University, Pediatric, Moscow, Russian Federation; ${ }^{3}$ National Medical Research Center of Children's Health, Genetic, Moscow, Russian Federation

Background: Macrophage activation syndrome (MAS) is a life-threatening complication of systemic-onset juvenile idiopathic arthritis (sJIA) characterized by fever, hepatosplenomegaly, lymphadenopathy, coagulopathy, and rapid development of multiple organ failure. MAS is triggered by viral and bacterial infections, most often Epstein-Barr viruses, cytomegalovirus, influenza and parainfluenza viruses, parvavirus B19, yersiniosis, salmonellosis, sepsis.

Despite modern diagnostic and treatment technologies, MAS still remains a formidable complication of SJIA, it is characterized by an aggressive course, a heterogeneous clinical presentation, especially in conditions of treatment with genetically engineered biological drugs, an ambiguous response to pathogenetic therapy and is accompanied by mortality in $5-10 \%$ of patients.

Objectives: To analyze the clinical and laboratory features of MAS in children with sJIA and to study the genetic predisposition of this syndrome.

Methods: The study included 24 patients with MAS who are being followed up in the rheumatology department of the National Medical Research Center of Children's Health, Moscow. The clinical presentation and laboratory manifestations were assessed in 24 , and genetic features were described in 7 patients using a new generation sequencing with further biostatistical processing of the obtained genetic data.

Results: Of 24 patients, $23(98 \%)$ had fever, $16(68 \%)$ patients had rash, 17 $(72 \%)$ - organomegaly, $4(16 \%)$ - polyserositis, $2(7 \%)$ - myalgia and myopathy. All $24(100 \%)$ patients had an increase in ferritin level of more than $684 \mathrm{ng} /$ $\mathrm{ml}, 98 \%$ of them had a high level of lactate dehydrogenase (LDH) and $97 \%$ - a high level of triglycerides. In CBC, cytopenia was found in $80 \%$ of children: in $54 \%$ - erythrocytopenia, in $74 \%$ - leukopenia, in $88 \%$ - thrombocytopenia, in $15 \%$ - sharp decrease in erythrocyte sedimentation rate. In a coagulogram of 24 patients, $90 \%$ had an increase in D-dimer, $85 \%$ had a decrease in fibrinogen. Hyponatremia presented in $95 \%$ of patients. Thus, $85 \%$ of patients met the diagnostic criteria of the HLH-2004 protocol, adapted for children with SJIA. Genetic characteristics were analyzed in 7 children out of 94 patients with MAS. They are presented in Table 1. These patients have rare and frequent variants, as well as genes polymorphisms that are associated with macrophage activation syndrome.

Table 1. The number of genetic variants in children with MAS $(n=7)$.

Gene Patient № 1 Patient №2 Patient № 3 Patient № 4 Patient №5 Patient №6 Patient №7

\begin{tabular}{lccccccc}
\hline LYST & 0 & 24 & 7 & 3 & 4 & 6 & 4 \\
NLRC4 & 4 & 4 & 4 & 4 & 4 & 6 & 3 \\
NLRP12 & 5 & 10 & 6 & 4 & 4 & 12 & 4 \\
NLRP3 & 1 & 8 & 5 & 5 & 5 & 7 & 5 \\
TNFAIP3 & 2 & 2 & 2 & 0 & 2 & 2 & 2 \\
UNC13D & 18 & 2 & 5 & 10 & 18 & 26 & 18 \\
XIAP & 1 & 1 & 0 & 0 & 1 & 3 & 1 \\
\hline
\end{tabular}

Conclusion: The macrophage activation syndrome has a typical clinical presentation, there are clinical and laboratory manifestations: fever, hyperferritinemia, cytopenia, hyponatremia, increased levels of LDH and triglycerides, based on which, a diagnosis can be made. Patients with MAS at our center also had genetic characteristics that predisposed to the development of this condition. REFERENCES:

[1] Crayne CB, Albeituni S, Nichols KE, Cron RQ. The Immunology of Macrophage Activation Syndrome. Front Immunol. 2019 Feb 1;10:119. doi: 10.3389/fimmu.2019.00119. PMID: 30774631; PMCID: PMC6367262.

[2] Henderson LA, Cron RQ. Macrophage Activation Syndrome and Secondary Hemophagocytic Lymphohistiocytosis in Childhood Inflammatory Disorders: Diagnosis and Management. Paediatr Drugs. 2020 Feb;22(1):29-44. doi: 10.1007/s40272-019-00367-1. PMID: 31732958; PMCID: PMC7334831.

[3] Ravelli A, Davì S, Minoia F, Martini A, Cron RQ. Macrophage Activation Syndrome. Hematol Oncol Clin North Am. 2015 Oct;29(5):927-41. doi: 10.1016/j. hoc.2015.06.010. Epub 2015 Aug 25. PMID: 26461152.

Disclosure of Interests: None declared

DOI: 10.1136/annrheumdis-2021-eular.1491

\section{AB0722 \\ TREATMENT RESPONSE TO METHOTREXATE MONOTHERAPY IN ADULTS WITH JUVENILE IDIOPATHIC ARTHRITIS: DATA FROM THE NOR- DMARD STUDY}

I. Bardan ${ }^{1}$, K. M. Fagerli², J. Sexton ${ }^{2}$, G. Bakland ${ }^{3}$, P. Mielnik ${ }^{4}$, L. M. Paucar Loli $^{5}$, T. K. Kvien ${ }^{1,2}$, E. Kristianslund ${ }^{2}$, A. B. Aga ${ }^{2,6}{ }^{1}{ }^{1}$ University of Oslo, Faculty of Medicine, Oslo, Norway; ${ }^{2}$ Diakonhjemmet Hospital, Division of Rheumatology and Research, Oslo, Norway; ${ }^{3}$ University Hospital Northern Norway, Department of Rheumatology, Tromsø, Norway; ${ }^{4} \mathrm{Helse}$ Førde, Section for Rheumatology, Department for Neurology, Rheumatology and Physical Medicine, Førde, Norway; ${ }^{5}$ Lillehammer Hospital for Rheumatic Diseases, Department of Rheumatology, Oslo, Norway; ${ }^{6}$ Oslo University Hospital, Department of Rheumatology, Oslo, Norway

Background: Juvenile idiopathic arthritis (JIA) can cause considerable pain and disability in childhood and adulthood. The number of studies exploring the efficacy of medications in adult JIA patients is limited. Methotrexate (MTX) is a commonly used medication for this patient group.

Objectives: To explore the effects of MTX monotherapy (mono) on disease activity in adult patients diagnosed with JIA, compared to a weighted rheumatoid arthritis (RA) cohort.

Methods: Data from NOR-DMARD, a longitudinal observational study enrolling patients $>18$ years starting or switching DMARD treatment for inflammatory joint disease, was used [1]. Patients starting MTX mono treatment, and with a clinical diagnosis of JIA or other inflammatory arthropathies diagnosed before the age of 16 years, were identified from the study population. RA patients starting the same treatment regimen were included for comparative purposes.

Disease activity measurements and remission rates were collected at baseline, 3 and 6 months. Changes in disease activity and absolute remission rates after 3 and 6 months were calculated. Remission rates and change in disease activity from baseline were compared between JIA patients and a weighted RA cohort with weights based on age and gender, using linear and logistic regression for continuous and categorical variables, respectively.

Results: 2201 patients were included in the analyses, $101 \mathrm{JIA}$ patients $(80.2 \%$ female, mean (SD) age 35.6 (13.0) years, mean (SD) diagnosis duration 24.8 (12.9) years), and 2100 RA patients (69.4\% female, mean (SD) age 56.6 (13.6) years, mean (SD) diagnosis duration 4.1 (8.1) years) were included in the analyses. Age, gender distribution and disease duration differed significantly between cohorts.

Both the JIA and RA group improved significantly across all disease activity measures from baseline to 3 and 6 months (Table 1). Both groups had a progressive increase in remission rates from baseline to 6 months (Table 1, Figure 1). The RA group had a significantly greater improvement in ESR after 3 months, SJC28 after 6 months and TJC28, DAS28, SDAI and MHAQ after 3 and 6 months. There were no significant group differences in remission rates.

Table 1.

\begin{tabular}{|c|c|c|c|c|c|c|c|c|c|}
\hline & \multicolumn{3}{|c|}{ Baseline } & \multicolumn{3}{|c|}{ Change to 3 months } & \multicolumn{3}{|c|}{ Change to 6 months } \\
\hline & $\mathrm{JIA}^{*}$ & $\mathbf{R A}^{*}$ & Diff. $^{\S}$ & JIA* $^{*}$ & $\mathbf{R A}^{*}$ & Diff. $^{\S}$ & $\mathrm{JIA}^{*}$ & $\mathbf{R A}^{*}$ & Diff. $^{\S}$ \\
\hline $\begin{array}{l}\text { ESR, } \\
\mathrm{mm} / \mathrm{h}\end{array}$ & $\begin{array}{c}20.4 \\
(18.2)\end{array}$ & $\begin{array}{c}28.7 \\
(22.2)\end{array}$ & $\begin{array}{c}3.7(-0.6 \text { to } \\
8.1)\end{array}$ & $\begin{array}{c}-3.1 \\
(15.8)\end{array}$ & $\begin{array}{c}-9.6 \\
(18.7)\end{array}$ & $\begin{array}{r}-5.7(-10.1 \\
\text { to }-1.4)\end{array}$ & $\begin{array}{c}-3.0 \\
(17.5)\end{array}$ & $\begin{array}{l}-11.3 \\
(19.8)\end{array}$ & $\begin{array}{c}-5.4(-10.8 \\
\text { to } \\
0.03)\end{array}$ \\
\hline SJC28 & $\begin{array}{c}3.9 \\
(4.8)\end{array}$ & $\begin{array}{c}6.9 \\
(5.7)\end{array}$ & $\begin{array}{c}2.0(0.9 \text { to } \\
3.2)\end{array}$ & $\begin{array}{l}-1.8 \\
(3.3)\end{array}$ & $\begin{array}{l}-3.5 \\
(5.5)\end{array}$ & $\begin{array}{c}-0.9(-1.9 \text { to } \\
0.02)\end{array}$ & $\begin{array}{l}-1.8 \\
(3.3)\end{array}$ & $\begin{array}{l}-4.2 \\
(5.6)\end{array}$ & $\begin{array}{r}-1.5(-2.6 \\
\text { to }-0.5)\end{array}$ \\
\hline TJC 28 & $\begin{array}{c}4.5 \\
(4.9)\end{array}$ & $\begin{array}{l}8.0 \\
(7.1)\end{array}$ & $\begin{array}{c}3.1 \text { (1.9 to } \\
4.2)\end{array}$ & $\begin{array}{l}-0.8 \\
(4.2)\end{array}$ & $\begin{array}{l}-3.5 \\
(7.4)\end{array}$ & $\begin{array}{c}-1.9(-3.1 \text { to } \\
-0.7)\end{array}$ & $\begin{array}{l}-1.4 \\
(3.8)\end{array}$ & $\begin{array}{l}-4.0 \\
(6.8)\end{array}$ & $\begin{array}{r}-2.3(-3.4 \\
\text { to }-1.1)\end{array}$ \\
\hline DAS28 & $\begin{array}{c}4.0 \\
(1.3)\end{array}$ & $\begin{array}{c}4.9 \\
(1.3)\end{array}$ & $\begin{array}{c}0.6(0.2 \text { to } \\
0.9)\end{array}$ & $\begin{array}{l}-0.6 \\
(1.2)\end{array}$ & $\begin{array}{l}-1.2 \\
(1.5)\end{array}$ & $\begin{array}{c}-0.5(-0.9 \text { to } \\
-0.2)\end{array}$ & $\begin{array}{l}-0.7 \\
(1.2)\end{array}$ & $\begin{array}{l}-1.4 \\
(1.5)\end{array}$ & $\begin{array}{r}-0.6(-1.0 \\
\text { to }-0.2)\end{array}$ \\
\hline SDAI & $\begin{array}{c}18.3 \\
(11.3)\end{array}$ & $\begin{array}{c}26.0 \\
(13.6)\end{array}$ & $\begin{array}{c}5.6 \text { (2.7 to } \\
8.4)\end{array}$ & $\begin{array}{l}-6.0 \\
(9.7)\end{array}$ & $\begin{array}{c}-11.0 \\
(14.0)\end{array}$ & $\begin{array}{c}-3.1(-5.9 \text { to } \\
-0.2)\end{array}$ & $\begin{array}{l}-6.3 \\
(8.2)\end{array}$ & $\begin{array}{l}-12.8 \\
(14.2)\end{array}$ & $\begin{array}{r}-5.1(-7.8 \\
\text { to }-2.2)\end{array}$ \\
\hline PGA & $\begin{array}{c}51.0 \\
(24.6)\end{array}$ & $\begin{array}{c}48.3 \\
(24.3)\end{array}$ & $\begin{array}{c}-4.5(-10.0 \\
\text { to } 1.1)\end{array}$ & $\begin{array}{l}-13.2 \\
(25.3)\end{array}$ & $\begin{array}{l}-14.7 \\
(26.5)\end{array}$ & $\begin{array}{c}-1.0(-7.4 \text { to } \\
5.3)\end{array}$ & $\begin{array}{c}-11.3 \\
(23.8)\end{array}$ & $\begin{array}{l}-14.3 \\
(26.7)\end{array}$ & $\begin{array}{r}-4.6(-11.9 \\
\text { to } 2.7)\end{array}$ \\
\hline MHAQ & $\begin{array}{c}0.5 \\
(0.5)\end{array}$ & $\begin{array}{c}0.7 \\
(0.5)\end{array}$ & $\begin{array}{r}0.1(-0.05 \\
\text { to } 0.2)\end{array}$ & $\begin{array}{l}-0.2 \\
(0.3)\end{array}$ & $\begin{array}{l}-0.2 \\
(0.5)\end{array}$ & $\begin{array}{c}-0.1(-0.2 \text { to } \\
-0.0)\end{array}$ & $\begin{array}{l}-0.1 \\
(0.3)\end{array}$ & $\begin{array}{l}-0.2 \\
(0.5)\end{array}$ & $\begin{array}{c}-0.16 \\
(-0.3 \text { to } \\
-0.1)\end{array}$ \\
\hline
\end{tabular}

${ }^{*}$ Mean $(\mathrm{SD})^{\S}$ Weighted group difference, RA coefficient (95\% confidence interval)

Conclusion: Adult JIA patients had significant improvement across all the presented disease activity measures 3 and 6 months after treatment initiation with MTX mono. The magnitude of improvement was smaller than in the RA group, but JIA patients obtained remission at similar rates as RA patients. 